\title{
SIFAT KUALITATIF, MORFOMETRIK, DAN KARKAS BURUNG AYAMAN (Gallirallus phillippensis) DI KAMPUNG MACUAN DISTRIK MASNI KABUPATEN MANOKWARI
}

\author{
(QUALITATIVE TRAIT, MORPHOMETRIC, CARCASS AND MEAT NUTRITIONAL CONTENT \\ OF AYAMAN BIRD (Gallirallus philippensis) IN MACUAN VILLAGE, MASNI SUBDISTRICT, \\ MANOKWARI REGENCY)
}

\author{
Yusak Jeckson Sada, Irba Unggul Warsono* dan A. G. Murwanto* \\ Staf Unit Pelaksana Teknis Daerah (UPTD) Balai Pembibitan Ternak \\ dan Hijauan Makanan Ternak Papua Barat \\ * Staf Pengajar Fakultas Peternakan Universitas Papua
}

Diajukan: 5 januari 2018 ; Diterima: 1 Maret 2018

\begin{abstract}
ABSTRAK
Burung Ayaman (Gallirallus philippensis). sering diburu untuk dimanfatkan sebagai sumber daging oleh penduduk di Dataran Lembah Prafi khususnya Kampung Macuan. Tujuan penelitian ini adalah untuk mengetahui sifat kualitatif, ukuran morfometrik, kualitas karkas, serta kandungan gizi daging Burung Ayaman (Galllirallus philippensis). 56 ekor burung ayaman (28 jantan dan 28 betina) digunakan dalam penelitian ini. Metode penelitian yang digunakan metode deskriptif dengan teknik studi kasus. Data yang diperoleh dianalisis menggunakan uji t. Sifat kualitatif yang meliputi warna bulu pada berbagai bagian tubuh, warna paruh, shank dan bentuk shank antara burung ayaman (Gallirallus philippensis) jantan dan betina sama, kecuali warna paruh dan shank ada perbedaan. Ukuran panjang paruh dan panjang sayap antara burung ayaman jantan dan betina tidak berbeda nyata, sedangkan panjang ekor dan panjang jari kaki tengah lebih panjang dibanding pada betina. Berat karkas dan berat bagian-bagian karkas pada jantan lebih berat dari pada betina. Tetapi memiliki persentase karkas yang sama antara Burung Ayaman jantan dan betina. Kandungan gizi daging meliputi; protein, lemak, energi dan kolesterol pada Burung Ayaman jantan dan betina relatif sama
\end{abstract}

Kata Kunci: Burung Ayaman, Sifat Kualitatif, Ukuran Morfometrik, Kualitas Karkas

\begin{abstract}
Ayaman bird (Gallirallusphilippensis) usually hunted for meat for people in Prafi, specifically in Macuan village. The aim of this research was to determine the qualitative, morphometric measurement, carcass quality and meat nutritional contain of Ayaman bird. Fifty six head of ayaman birds (28 males and 28 females) was used in this research. Descriptive method with case study technique was used. Data was analyzed with test. Qualitative trait such as feather color, shank shape were the same between male and female bird except for the color of the beak and shank were different. Male and female beak and wings length were not significantly different, while tail and middle finger of the male were longer than the female bird. Carcass, hind and fore carcassweight were heavier in male than female bird, but carcass percentage were the same between male and female bird. Meat nutritional contain such as protein, fat, energy and cholesterol were the same between male and female bird.
\end{abstract}

Key words: Ayaman bird, qualitative trait, Morphometric measurement, Carcass quality

\section{PENDAHULUAN}

Di Indonesia saat ini konsumsi protein hewani masih di bawah standar gizi nasional. Tingkat konsumsi daging hanya sebesar 4,19 gram/kapita/hari, masih jauh dari standar konsumsi protein hewani 6 gram/kapita/hari dari Widya Karya Nasional (BPS, 2014).
Belum tercapainya standar konsumsi tersebut disebabkan oleh salah satu faktor ialah produksi daging dalam negeri yang masih belum mencukupi kebutuhan konsumsi. Pada tahun 2014 produksi daging mencapai 406.000 ton, sedangkan kebutuhan konsumsi daging sebesar 653.000 ton (Ditjen Peternakan dan 
Kesehatan Hewan, 2015). Upaya-upaya untuk mengatasi masalah kesenjangan tersebut yang dapat dilakukan antara lain: impor sapi bakalan, daging beku sapi dan kerbau, peningkatan produktivitas usaha berbagai peternakan, Program peningkatan swasembada sapi potong, Program pengembangan plasma nutfa lokal dan pemanfaatan satwa liar penghasil daging.

Satwa liar yang banyak dimanfaatkan oleh masyarakat sebagai sumber protein hewani umumnya berasal dari hewan mamalia dan burung. Satwa liar di Indonesia mempunyai keanekaragaman spesies yang tinggi. Jumlah mamalia sebanyak 515 spesies dengan tingkat endemik 21,7 \%, reptil banyak 511 spesies dengan tingkat endemik 14,4\%,dan burung memiliki jumlah 1.534 spesies dengan tingkat endemik 16,2\% (Konphalindo,1994). Salah satu daerah yang mempunyai banyak spesies burung adalah di Papua.

Di kawasan Papua terdapatsekitar 602 spesies burung dengan jumlah spesies endemik 50 \% (Beehler, Pratt and Zimmerman, 2001). Jenis burung yang sering dimanfaatkan sebagai sumber daging adalah burung Kasuari (Casuarius casuarius), Mambruk (Goura Victoria), Tauntaun atau Burung Rangkong/ Enggang (Buceros), Kumkum (Ducula pinon), dan Maleo (Aepypodius. sp).

Dataran Lembah Prafi khususnya Kampung Macuan terdapat Burung Ayaman (Gallirallus philippensis). Secara umum burung ini dikenal dengan nama burung Mandar Padi Kalung Kuning. Burung ini menurut data dari IUCN (2012) masuk dalam kriteria least concern (LC) atau belum mengkhawatirkan dari kepunahan. Burung ini sering diburu untuk dimanfatkan sebagai sumber daging oleh penduduk setempat.

Tujuan penelitian ini adalah untuk mengetahui sifat kualitatif, ukuran morfometrik, kualitas karkas, serta kandungan gizi daging Burung Ayaman (Galllirallus philippensis).

Hasil penelitian ini diharapkan bermanfaat sebagai informasi awal untuk menentukan kajian-kajian lanjutan dalam rangka upaya budidaya Burung Ayaman (Gallirallus phillippensis).

\section{MATERI DAN METODE}

Penelitian ini dilaksanakan di Kampung Macuan Distrik Masni Kabupaten Manokwari dan Laboratorium BALITNAK Bogor. Pelaksanaannya dari tanggal 24 Oktober sampai dengan 24 Desember 2016 (3 bulan).

Objek Penelitian ini adalah Burung Ayaman (Galllirallus philippensis) dengan jumlah 56 ekor. Alat yang digunakan adalah alat tulis menulis, timbangan digital, kamera, komputer, mistar ukur, jangka sorong, jerat dan alat bedah.

Metode penelitian yang digunakan dalam penelitian ini adalah metode deskriptif dengan teknik studi kasus. Sebagai kasus dalam penelitian ini adalah Burung Ayaman (Galliralus philippensis) yang ada di Kampung Macuan Distrik Masni Kabupaten Manokwari.

Metode pengambilan contoh burung menggunakan metode pengambilan contoh aksidental sesuai burung yang terjerat (Sugiyono, 2006). Jumlah contoh burung sebanyak 56 ekor. Masing-masing pengamatan adalah sebagai berikut; untuk pengamatan sifat kualitatif digunakan 10 ekor (5 ekor jantan dan 5 ekor betina, ukuran morfometrik digunakan 40 ekor (20 jantan dan 20 betina), selanjutnya obyek yang sama digunakan untuk mengukur karkas ( 20 ekor jantan 20 ekor betina) dan pengamatan kandungan gisi digunakan 6 ekor ( 3 ekor jantan dan 3 ekor betina).

\section{Metode Pengumpulan Data}

1. Sifat kualitatif

Sifat-sifat kualitatif dikumpulkan dengan cara melakukan pengamatan atau observasi langsung. Sifat-sifat kualitatif yang diamati warna bulu pada berbagai bagian tubuh, warna paruh, dan warna shank, bentuk shank.

\section{Ukuran morfometrik}

Ukuran morfometrik diukur dengan menggunakan kaliper. Data morfometrik yang diukur ialah: panjang paruh, panjang sayap, panjang ekor dan panjang shank, serta panjang jari kaki tengah.

3. Karkas

Data karkas terdiri dari berat hidup, berat karkas, persentase karkas, berat karkas depan dan berat karkas belakang. Pengumpulan data berat hidup, berat karkas, berat karkas depan 
dan karkas belakang dilakukan dengan penimbangan, sedangkan persentase karkas dilakukan dengan perhitungan.

\section{Kandungan gizi}

Kandungan gizi daging burung diperoleh dengan cara melakukan analisis kimia di Laboratorium Balitnak Bogor. Prosedur pengiriman adalah sebagai berikut: Sebelum dikirim karkas dimasukan di dalam refrigerator sampai beku, lalu di masukan ke dalam cool box (ukuran $20 \times 20 \mathrm{~cm}$ ) yang sudah ada es batunya. Cool box harus ditutup sampai kedap udara. Kemudian bahan tersebut dikirim ke laboratorium untuk dianalisis, maksimal 24 jam sampai di BALITNAK Bogor. Data kandungan gizi yang dianalisis terdiri atas; protein, lemak, energi dan kolesterol.

\section{Peubah yang Diteliti}

1. Sifat kualitatif.

a. Warna bulu pada berbagai bagian tubuh.

b. Warna paruh dan shank.

c. Bentuk shank.

2. Ukuran morfometrik.

a. Panjang paruh $(\mathrm{cm})$.

Panjang paruh diukur dari ujung pangkal sampai ujung paruh. Gambar cara mengukur panjang paruh dapat di lihat pada lampiran 6. (Lambey, 2013)

b. Panjang sayap (cm).

Panjang sayap diukur dari ujung scapula (lipatan sendi sayap) sampai ujung bulu sayap primer terpanjang tanpa penekanan (alami). Gambar cara mengukur panjang sayap dapat di lihat pada lampiran 6. (Lambey, 2013)

c. Panjang ekor $(\mathrm{cm})$.

Panjang ekor diukur antara pangkal bulu ekor sampai ujung bulu terpanjang. Gambar cara mengukur panjang ekor dapat dilihat pada lampiran 6. (Lambey, 2013)

d. Panjang Shank (cm).

Panjang shank diukur dari belakang sendi intertarsal kearah bawah sampai daerah sole. Gambar cara mengukur panjang Shank dapat di lihat pada lampiran 6. (Lambey, 2013).

e. Panjang Jari Kaki Tengah (cm).
Diukur mulai dari pangkal hingga ujung kuku. Gambar cara mengukur panjang jari kaki tengah dapat di lihat pada lampiran 6. (Koyong.S.S dkk, 2014)

3. Karkas.

a. Berat karkas (gram)

Berat karkas adalah berat hidup dikurangi kepala, darah, kaki, jeroan dan bulu-bulu.

b. Persentase karkas (\%)

Persentase karkas $=\frac{\text { berat } \text { karkas }}{\text { berat } \text { hidup }} \times 100 \%$

c. Berat bagian-bagian karkas (gram)

Bagian-bagian karkas terdiri atas dua bagian yaitu karkas depan dan karkas belakang yang dipotong pada tulang rusuk terakhir.

4. Kandungan gizi.

a. Protein : $\% \quad \mathrm{~N}=$

$$
\frac{(S-B) \times N H C L \times 14}{W \times 1000} \times 100 \%
$$

Keterangan: $\mathrm{S}=$ volume titran sampel (ML), B = volume titran blangko(mL), w = bobot sampel kering (mg), 14 = bobot atom nitrogen. Kadar protein diperoleh dengan mengalikan kadar nitrogen dengan faktor perkalian untuk berbagai bahan pangan berkisar 5,18-6,38. Untuk protein daging, digunakan 6,25 (konversi nitrogen ke protein kasar).

b. Lemak.

Kadar lemak dihitung dengan menggunakan metode EkstraksiSoxhlet. Sampel yang akan diekstraksi lemaknya terlebih dahulu dikeringkan dalam oven vakum dan dihaluskan dengan blender menjadi tepung. Lemak hasil ekstraksi dipanaskan dalam oven pada suhu $105^{\circ} \mathrm{C}$ untuk menghilangkan pelarutnya (dietil eter), Kemudian dikeluarkan, didinginkan dalam desikator dan ditimbang berat lemaknya (Warsono, 2009). Perhitungan kadar lemak daging mengikuti rumus:

Lemak (\%)

$=\frac{\text { berat lemak hasil ekstraksi }}{\text { sampel }(\mathrm{mg})} \times 100$

c. Kolesterol.

Kadar kolesterol diukur menggunakan kit dengan metode " CHOD-PAD”: 
Enzymmatic photometric test (Diasys Diagnostic Systems GmbH, 2005).

d. Gross energy diukur dengan bom calorimeter.

\section{Analisis Data}

1. Analisis data sifat kualitatif

Sifat-sifat kualitatif dianalisis dengan menggunakan analisis statistika deskriptif.

2. Analisis data ukuran morfometrik

Ukuran morfometrik dianalisis dengan menggunakan analisis statistika deskriptif.

3. Analisis data karkas.

Data karkas dianalisis dengan menggunakan analisis Uji t untuk

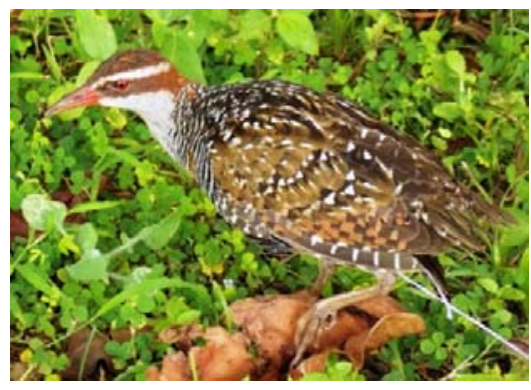

Gambar 1. Burung Ayaman (Gallirallus Philippensis) Betina

Ciri- ciri burung ayaman betina sebagai berikut: Kepala bagian atas berbintik hitam kecoklatan, terdapat garis putih diatas mata, warna coklat dari pangkal paruh sampai bagian kepala belakang, Paruh warna coklat Pink lebih terang. Bagian leher berwarna abu-abu dan terdapat warna coklat terang sperti kalung. (sehingga burung ini sering disebut burung mandar padi kalung kuning). Warna bulu membandingkan antara burung jantan dan burung betina.

\section{HASIL DAN PEMBAHASAN}

\section{Sifat Kualitatif}

Sifat kualitatif Burung Ayaman (Gallirallus philippensis) yang meliputi warna bulu pada berbagai bagian tubuh, warna paruh, shank dan bentuk shank.

Sifat kualitatif atau ciri-ciri burung ayaman (Gallirallus philippensis) betina dapat dilihat pada Gambar 1

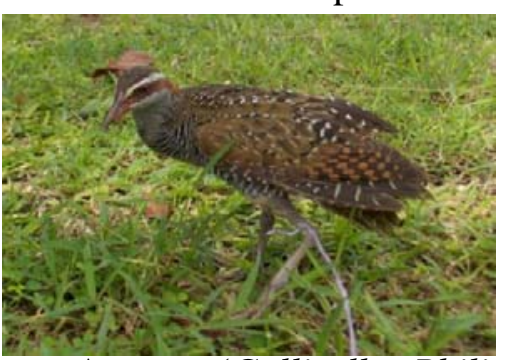

Gambar 2. Burung Ayaman (Gallirallus Philippensis) Jantan

Ciri-ciri Burung Ayaman Jantan: Ciri-ciri warna bulu jantan sama dengan ciri-ciri warna bulu betina pada berbagai bagian tubuh. Dengan demikian burung ini bersifat mempunyai sifat monomorfis. Hal ini sejalan dengan penelitian Lambey, (2013) bahwa burung Weris (Gallirallus philippensis) tidak bagian dada lurik hitam dan abu-abu. Bagian punggung berwarna totol coklat hitam putih. Kemudian bagian sayap lurik coklat hitam dan putih. Warna lurik coklat pada pada ekor. Warna shank betina coklat pink lebih terang. Bentuk shank satu jari menghadap ke belakang sedangkan tiga jari menyatu ke depan. Sedangkan ciri-ciri burung Ayaman Jantan dapat di lihat pada Gambar 2. 

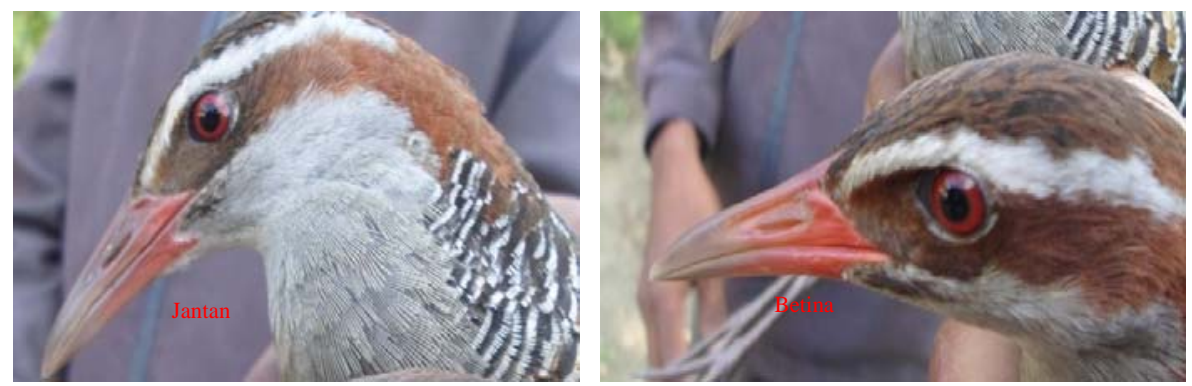

Gambar 3. Paruh Burung Ayaman (Gallirallus Philippensis)

Pada kedua gambar di atas terlihat bahwa ada perbedaan warna antara warna paruh burung jantan dengan warna paruh burung betina. Warna paruh Burung Ayaman jantan

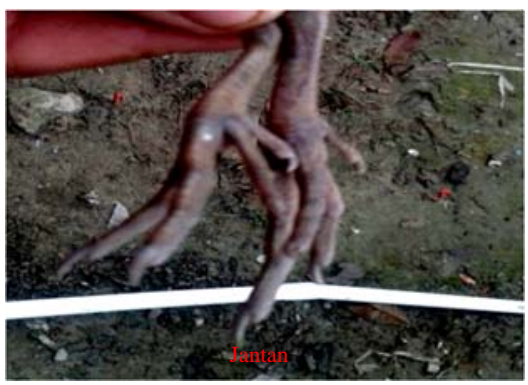

Gambar 4. Warna dan Bentuk Shank Burung Ayaman

Pada Gambar 5 diatas warna shank burung jantan coklat pink gelap dan betina coklat pink lebih terang. Bentuk shank baik burung jatan atau betina adalah sama yaitu satu jari menghadap ke belakang sedang tiga jari menyatu ke depan. Hal ini sesuai dengan Proco \& Lynch (1993) bahwa bentuk shank Burung Ayaman (Gallirallus philippens) adalah sindactyl yaitu bentuk kaki yang coklat pink lebih gelap, sedangkan warna paruh Burung Ayaman betina coklat pink lebih terang.

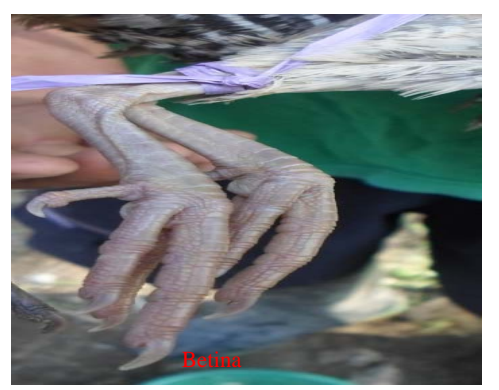

menyerupai anisodactyle namun ketiga jari depan menyatu seperti yang terdapat pada burung mandar atau burung weris dan raja udang.

\section{Ukuran Morfometrik:}

Hasil pengukuran morfometrik Burung Ayaman jantan dan betina dapat dilihat pada Tabel 1 di bawah ini.

Tabel 1. Ukuran Morfometrik Burung Ayaman (Gallirallus philippens)

\begin{tabular}{|c|c|c|c|c|c|c|c|}
\hline \multirow[b]{2}{*}{ Peubah } & \multicolumn{4}{|c|}{ Betina } & \multicolumn{2}{|c|}{ Jantan } & \multirow{2}{*}{$\begin{array}{c}\text { Peluang Hasi } \\
\text { Uji t }\end{array}$} \\
\hline & $\mathrm{N}$ & Rata-rata & SD & $\mathrm{N}$ & Rata-rata & SD & \\
\hline Panjang Paruh (cm) & 20 & 2,660 & 0,260 & 20 & 2,795 & 0,319 & 0,151 \\
\hline Panjang Sayap (cm) & 20 & 18,315 & 3,125 & 20 & 19,440 & 2,855 & 0,242 \\
\hline Panjang Ekor (cm) & 20 & $4,910^{\mathrm{a}}$ & 1,283 & 20 & $5,730^{\mathrm{b}}$ & 0,863 & 0,023 \\
\hline Panjang Shank (cm) & 20 & 6,015 & 8,470 & 20 & 4.285 & 0,157 & 0,373 \\
\hline Panjang Jari kaki tengah $(\mathrm{cm})$ & 20 & $4,095^{\mathrm{A}}$ & 0,069 & 20 & $4,255^{\mathrm{B}}$ & 0,150 & 0,000 \\
\hline
\end{tabular}

*) superskrip huruf kecil yang berbeda pada baris yang sama menunjukkan perbedaan yang nyata $(\mathrm{P}<0,05)$ dan superskrip huruf besar yang berbeda pada baris yang sama menunjukkan perbedaan yang sangat nyata $(\mathrm{P}<0,01)$. 


\section{Panjang Paruh}

Dari Tabel 1 di atas menunjukkan bahwa rata-rata panjang paruh burung ayaman jantan dan betina tidak berbeda nyata $(\mathrm{P}>0,05)$. Hasil penelitian ini tidak berbeda jauh dengan hasil penelitian Lambey (2013) pada burung weris jantan dengan rata-rata panjang paruh sebesar 2,92 cm, sedangkan betina 2,64 cm.

\section{Panjang Sayap}

Panjang sayap burung ayaman jantan dan betina secara statistik tidak berbeda nyata $(\mathrm{P}>0,05)$. Hasil penelitian ini tidak berbeda jauh dengan hasil penelitian Lambey (2013) pada burung weris jantan dengan rata-rata panjang sayap sebesar 19,25 cm, sedangkan betina sebesar $18,57 \mathrm{~cm}$.

\section{Panjang Ekor}

Panjang ekor burung ayaman jantan secara statistik berbeda nyata $(\mathrm{P}<0,05)$ lebih panjang dari panjang ekor burung betina. Hasil penelitian ini tidak berbeda jauh dengan hasil penelitian Lambey (2013) pada burung weris jantan dengan rata-rata panjang ekor sebesar $6,27 \mathrm{~cm}$, sedangkan betina sebesar $6,29 \mathrm{~cm}$. Perbedaan ini diduga dipengaruhi oleh hormone testoteron. Bulu ekor terpanjang adalah bulu yang didimiliki jantan. Hal ini dapat membantu untuk membedakan jantan dan betina dari bulu ekor Burung Ayaman.

\section{Panjang Shank}

Tabel 2. Berat Hidup dan Kualitas Karkas Burung Ayaman (Gallirallus philippens)

\begin{tabular}{|c|c|c|c|c|c|c|c|}
\hline \multirow[b]{2}{*}{ Peubah } & \multicolumn{4}{|c|}{ Betina } & \multicolumn{2}{|c|}{ Jantan } & \multirow{2}{*}{$\begin{array}{c}\text { Peluang Hasil } \\
\text { Uji t }\end{array}$} \\
\hline & $\mathrm{N}$ & $\begin{array}{l}\text { Rata- } \\
\text { Rata }\end{array}$ & SD & $\mathrm{N}$ & $\begin{array}{l}\text { Rata- } \\
\text { Rata }\end{array}$ & SD & \\
\hline Berat Hidup (gr) & 20 & $154,500^{\mathrm{A}}$ & 18,458 & 20 & $172,200^{\mathrm{B}}$ & 15,426 & 0,002 \\
\hline Berat Karkas (gr) & 20 & $97,200^{\mathrm{A}}$ & 12,556 & 20 & $108,700^{\mathrm{B}}$ & 9,620 & 0,002 \\
\hline $\begin{array}{l}\text { Persentasi Karkas } \\
(\%)\end{array}$ & 20 & 62,987 & 4,366 & 20 & 63,164 & 2,049 & 0,871 \\
\hline $\begin{array}{l}\text { Berat Karkas } \\
\text { Depan (gr) }\end{array}$ & 20 & $48,850^{\mathrm{a}}$ & 6,706 & 20 & $53,300^{\mathrm{b}}$ & 4,964 & 0,022 \\
\hline $\begin{array}{l}\text { Berat Karkas } \\
\text { Belakang (gr) }\end{array}$ & 20 & $48,350^{\mathrm{A}}$ & 7,343 & 20 & $55,00^{\mathrm{B}}$ & 5,703 & 0,003 \\
\hline
\end{tabular}

\section{Berat Hidup}

Berat hidup merupakan bobot burung yang ditimbang pada saat burung masih dalam keadan hidup. Hasil uji t menunjukkan bahwa
Dari Tabel 1 di atas menunjukkan bahwa rata-rata panjang shank burung ayaman jantan dan betina secara statistik tidak berbeda nyata $(\mathrm{P}>0,05)$. Hasil penelitian ini relatif sama dengan hasil penelitian Lambey, (2013) Panjang shank burung weris betina 4,13 \pm 0,36 sedangkan jantan 4,34 $\pm 0,41$.

\section{Panjang Jari Kaki Tengah}

Dari Tabel 1 di atas menunjukkan bahwa rata-rata panjang jari burung ayaman jantan dan betina secara statistik berbeda sangat nyata $(\mathrm{P}<0,01)$. Perbedaan sangat nyata antara panjang jari kaki tengah jantan dan betina diduga karena digunakan untuk kepentingan taksonomi yang berkaitan dengan posisi burung saat bertengger dan mengais makan diatas tanah. Sedangkan menurut Koyong. S.S dkk, (2014) bahwa panjang jari kaki tengah Gallirallus philippensis berkisar antara 3.6$4.2 \mathrm{~cm}$, dengan rataan $3.96 \mathrm{~cm}$. Adapun Gallirallus torquatus dari berkisar antara 4.1$4.3 \mathrm{~cm}$, dengan rataan $4.18 \mathrm{~cm}$. Selanjutnya Koyong.S.S dkk, (2014) menyatakan bahwa posisi jari-jari dapat digunakan untuk kepentingan taksonomi yang berkaitan dengan posisi burung saat bertengger atau pun tidak bertengger.

\section{Karkas}

Berat hidup dan kualitas karkas Burung Ayaman dapat dilihat pada Tabel 2 di bawah ini. berat hidup Burung Ayaman jantan sangat nyata $(\mathrm{P}<0,01)$ lebih berat dari burung betina (lampiran 1, 3 dan 5). Perbedaan berat hidup yang besar antara burung jantan dan betina 
sama dengan yang terdapat pada ayam kampung. Berat hidup burung yang diteliti lebih rendah bila dibandingkan dengan hasil penelitian Lambey, (2013). Hasil penelitian Lambey, (2013) berat hidup burung weris jantan sebesar 185,73 gr dan betina 161,80 gr. Tingginya berat burung jantan dibandingkan burung betina dikarenakan oleh hormon kelamin jantan terutama androgen. Menurut Harfez dan Dyer,(1969) yang disitasi Soeparno, (1992) bahwa hormon kelamin jantan (androgen) mengakibatkan pertumbuhan yang lebih cepat pada hewan jantan dibanding hewan betina. Selanjutnya dijelaskan pula bahwa hormon androgen dapat menstimulasi sintesis protein pada otot dan penurunan lemak tubuh.

\section{Berat Karkas}

Berat karkas adalah berat hidup dikurangi kepala, darah, kaki (batas tarsal), jerohan dan bulu. Hasil uji t ( lampiran 5 ) menunjukan bahwa berat karkas burung jantan secara sangat nyata $(\mathrm{P}<0,01)$ berbeda dengan berat karkas betina. Hal ini sejalan dengan perbedaan antara berat hidup burung jantan dan betina yang berbeda secara sangat nyata $(\mathrm{P}<0,01)$.

Tingginya berat karkas burung ayaman jantan dibandingkan betina disebabkan bobot hidup burung jantan $(172,200$ gr) lebih besar dari pada bobot hidup betina $(155,500$ gr). Tingginya berat karkas yang dihasilkan oleh hewan berkaitan erat dengan bobot badannya. Menurut Leche (1973) cit Suparno (1992), bahwa peningkatan bobot badan akan diikuti pula dengan meningkatnya bobot karkas.

\section{Persentase Karkas}

Hasil penelitian (lampiran 1, 3 dan 5) menunjukkan bahwa persentase karkas Burung Ayaman jantan dan betina tidak berbeda nyata $(\mathrm{P}>0,05)$. Hasil penelitian Lambey (2013) persentase karkas burung weris tanpa membedakan jenis kelamin diperoleh sekitar 65,85\%. Hal tersebut menunjukkan hasil penelitian Lambey (2013) tidak berbeda jauh dengan hasil penelitian ini. Menurut Suparno (1992) bangsa hewan yang sama dapat menghasilkan komposisi karkas yang berbeda. Tinggi rendahnya persentasi karkas yang dihasilkan dapat dipengaruhi oleh banyak factor, seperti organ jerohan dan kualitas pakan yang dikonsumsi.

\section{Berat Karkas Depan dan Belakang}

Hasil penelitian (Lampiran 1, 3 dan 5) menunjukkan bahwa berat karkas bagian depan antara burung ayaman jantan dan betina berbeda nyata $(\mathrm{P}<0,05)$. Sedangkan berat karkas bagian belakang antara burung ayaman jantan dan betina berbeda sangat nyata $(\mathrm{P}<0,01)$. Perbedaan pada bagian karkas antara burung jantan dan betina sejalan dengan perbedaan pada keseluruhan berat karkas.

\section{KESIMPULAN DAN SARAN}

\section{Kesimpulan}

1. Sifat kualitatif yang meliputi warna bulu pada berbagai bagian tubuh, warna paruh, shank dan bentuk shank antara burung ayaman (Gallirallus philippensis) jantan dan betina sama, kecuali warna paruh dan shank ada perbedaan.

2. Ukuran panjang paruh dan panjang sayap antara burung ayaman jantan dan betina tidak berbeda nyata, sedangkan panjang ekor dan panjang jari kaki tengah lebih panjang dibanding pada betina.

3. Berat karkas dan berat bagian-bagian karkas pada jantan lebih berat dari pada betina. Tetapi memiliki persentase karkas yang sama antara Burung Ayaman jantan dan betina.

4. Kandungan gizi daging meliputi; protein, lemak, energi dan kolesterol pada Burung Ayaman jantan dan betina relatif sama

\section{Saran}

Perlu dilakukan penelitian lanjutan di penangkaran dengan memperhatikan aspekaspek teknik budidaya ternak unggas, karena Burung Ayaman memiliki potensi untuk dikembangkan seperti budidaya unggas lainnya.

\section{DAFTAR PUSTAKA}

Anggorodi. 1979. Ilmu Makanan Ternak Umum. Pt Gramedia. Jakarta

BPS, 2014. Badan Pusat Statistik, Republik Indonesia Jakarta. 
Bruce MB, Thane KP, Dale AZ dan Harry LB. 2001. Burung burung di Kawasan Papua, Papua Nugini, dan Pulau-Pulau Satelitnya. PUSLITBANG Biologi LIPI Bogor. Bogor.

Coates BJ, Bishop KD. 1997. Panduan Lapangan Burung-Burung di Kawasan Wallaca. Bird Life International.

Dedi R, dan Rachmat W, 2011. Pendugaan kadar kolesterol daging dan telur berdasarkan kadar kolesterol pada puyuh jepang. Jurnal Ilmu Ternak Vol.11,No.1,35-38. FAPET UNPAD. Bandung.

Ditjen PKH, 2015. Direktorat Jenderal Peternakan Kementerian Pertanian RI Jakarta.

Forrrest J.C. E.D. Aberle. H.B. Hedrick, M.D. Judge and R.A. Merkel. 1975. Principle of Meat Science W.H. Freeman and Company. San.Fransisco.

Girinda A. 1987. Biokimia Patologi Hewan. Fakultas Matematika dan Ilmu Pengetahuan Alam. Institut Pertanian Bogor. Bogor.

Kennedy RS, Gonsales PC, Dickinson EC, Miranda HC, fisher TH.200. A. Guide to the Birds of the Philippines. Oxford: Oxford University Press.

Konphalindo.1994. Konsorsium Pelestarian Lingkungan Hidup Indonesia. Jakarta.

Koyong SS, HR Wungouw, Lambey L, dan Laatung S. (2014). Morfometri burung weris Gallirallus philippensis dan burung weris Gallirallus torquatus di Kota Kotamobagu Sulawesi Utara. Jurnal Zootek, 34, 51-66.

Lambey, L.J. (2013). Kajian biologis, tingkah laku, reproduksi dan kekerabatan burung weris, gallirallus philppensis (gruiformes : rallidae) di minahasa sulawesi utara. Disertasi Tidak diterbitkan, Program Pascasarjana, IPB, Bogor.

Linder MC. 1992.Biokimia Nutrisi dan Metabolisme. Terjemahan: Aminudin Parakkasi. Universitas Indonesia. Jakarta.
Mansjoer SS dan H Martojo. 1977. Produktivitas ayam kampung dan ayam persilangan F1 (Kampung X RIR) pada pemeliharaan dalam kandang.

Morran ET and HR Orr. 1976. Influence strain on the yield of commercial part from the chicken broiler carcass. Journal Poultry Science 49:725-726.

Noor RR. 2008. Genetika Ternak. Edisi ke-4. Jakarta: Penebar Swadaya

Ozaki K. 2009. Morpological differences of sex and age in the Okinawa Rail Gallirallus Okinawae. Ornithol Sci 8:117124.

Priyatno MA. 2003. Mendirikan usaha pemotongan ayam. Penebar Swadaya, Jakarta.

Procto NS and PJ Lynch.1993. Manual of Ornithology: Avian structure and function Yale Univ. Press, New Haven.

Rasyad M dan IK Amirulla. 1982. Beternak Burung Dara. PT. Penebar Swadaya. Jakarta.

Rasyaf M dan IK Amrullah. 1982. Bertenak Burung Dara. PT Penebar Swadaya. Jakarta.

Rusila NY. 2003. Panduan Studi Burung Pantai. Bogor: Wetlands International Indonesia Programe.

Sugiyono. 2006. Statistika untuk penelitian. Cetakan ketujuh. Bandung: Cv Alfabeta. Bandung

Suparno. 1998. Ilmu dan Teknologi Daging. Gajah Mada University Press, Yogyakarta.

Tillman AD, H Hartadi, S Reksohadiprodjo, S Prawiro dan S Lebdosoekojo. 1991. Ilmu Makanan Ternak Dasar. Gajah Mada University Press. Fakultas Peternakan UGM. Yogyakarta.

Warsono IU. 2009. Sifat biologis dan karakteristik karkas dan daging bandikut (Echymipera Kalubu). Disertasi Tidak diterbitkan, Program Pascasarjana, IPB, Bogor. 